\title{
AN ANALYSIS THE USE OF VISUAL MEDIA IN TEACHING ENGLISH TO YOUNG LEARNERS
}

\author{
Riska Febriany Sofian', Anita Anggraeni ${ }^{2}$ \\ 1,2 IKIP Siliwangi \\ ${ }^{1}$ riskafebranysofian@ student.ikipsiliwangi.ac.id, ${ }^{2}$ anitaenglish26@gmail.com
}

\begin{abstract}
This research aims to describe the teacher's preparation and explain how the teacher utilized the media in teaching English in one of the elementary schools in Cimahi. This method used a descriptive qualitative. This research was conducted with two instruments. There is observation in the classroom and an interview with the teacher. The research subject was VIB grade students in one school in Cimahi. The result of this research that the teacher did three kinds of preparation, prepares a projector, understands the material for delivery to students and prepares the PowerPoint that uses in the classroom. In utilizing the media, the teacher uses a projector and PowerPoint as a media in teaching English.
\end{abstract}

Keywords: Visual Media, PowerPoint, Young Learners

\section{INTRODUCTION}

Teaching English to young learners is different from teaching English to adults. It is because the way children learn foreign languages is different from the way adults learn. Cahyati, Parmawati, and Atmawidjaja (2019) assume that teaching for young students especially English must have good planning such as teaching methods, good material, and techniques and approaches that will be used. The learning process of children requires something realistic. According to Pinter (2006:1), as cited in Lelawati, Dhiya, and Mailani (2018), young learners find it difficult to know an abstract thing because they have limited knowledge about the word. The teachers must make creative and interesting activities to make students enjoy, interested and active in the learning process so that they will not be bored or just sit quietly. According to Scott and Ytreberg (1990), as cited in Rahmadani (2019), children have very short attention and concentration span, they do more duplication of language and get it through hands, eyes, and ears. According to Azis and Rif'ah (2018), two factors prevent students from understanding English, the first is that students consider English difficult because vocabulary and English are not their native languages, the second is the teacher's less interactive factor in teaching English material to be interesting to students. The purpose of teaching English to young learners is to introduce English as a second language for them, build basic knowledge of English and give them motivation in the process of learning English by giving appreciation for their needs and interests in this language in the future.

Many types of media can be used by teachers in the process of teaching and learning English to young learners such as audio media, visual media, audio-visual media and the teacher itself as a model. According to Akmal (2019), there are types of media such as manual media and electronic media which are media that can be used in the teaching-learning process. Media manuals are like tools that are in the classroom or around the place of learning (blackboards, markers, erasers, leaflets (modules)). Electronic media such as computers, language laboratories, films, OHP, Infocus and goods that use electricity 
Visual media is a medium for conveying information to students through visuals Isnaini and Lisani (2019). According to Jannah in Pratama (2016) as cited in Harisma, Ilmiah, and Yana (2019) Visual media is one type of media that can be seen and touched by teachers and students related to research subjects. According to Heinich, et al (2002) as cited in Sanjaya, Batan, and Myartawan (2018) types of visual media are visuals that are not projected, visual projections, document cameras, overhead projections, slides, digital images, and digital image projections. Heinich, et al (2002) as cited in Senjaya, Batan, and Myartawan (2018) slides are a type of visual media.

The importance of using media for teaching is that the media can be used to help students in their studies so that the teaching and learning process is more effective and efficient. By using media, the concrete material is interesting and easier to understand. Lynch (2008) as cited in Mustafa, Hermandra, and Zulhafizh (2019) explains that the use of media can increase student willingness in the learning process. The media helps the teacher to convey the material to students more easily understood. Furnhan et al., (2005) as cited in Mustafa, Hermanda, and Zulhafizh (2019) explain that the use of student media is more interactive in the learning process in the classroom.

There are several advantages to using media in the teaching-learning process. That is; to increase student motivation, to avoid boredom of students, to make students easily understand teaching material, to make teaching and learning process more systematic explains Sukartiwi (1996) as cited in Senjaya, Batan, and Myartawan (2018). The problem is some educators still use the old method where educators only use one method and model of learning English, even though educators are required to use English learning methods and models more than one, it aims so that learning English in the classroom will be fun so that students become children who are children active, creative and innovative.

Therefore, the aim of this research includes two research questions are formulated in this study as follows:

a) what kind of preparation does the teacher have in utilizing instructional media?

b) how does the teacher utilize the instructional media in the classroom?

Several related researchers have conducted similar studies before. The first from Nurnaningsih and Arianti (2019), the teacher used YouTube as a media teaching the students with several treatments: a) gather some of the videos presented in PowerPoint, b) there is an explanation on Powerpoint that is presented with a video from Youtube, c) only used to support the media in learning, d) download some videos to practice other than in class. The teacher uses youtube as a media: a) can be displayed at the beginning for an introduction to the material, b) after the teacher explains, so students better understand the material through Youtube, c) can be displayed at the end for evaluation.

The second from Aziza \& Syafei (2018), Shawn the Train Cartoon Film serial media is effective for learning about English vocabulary and can build student interest in learning English vocabulary to make it more interesting for young learners.

Based on the explanation above, this research with the title "An Analysis the Use of Media in Teaching English to Young Learner".

\section{METHOD}

This research used a descriptive qualitative design. Burns and Grove (2009) cited in Mohajan (2018) stated that qualitative research is a systematic and subjective approach to highlight and explain daily life experiences and to further give them proper meaning. According to Rachmijati and Anggraeni (2019), qualitative research focuses only on understanding an issue rather than 
looking at the problem for generalization purposes. The purpose of qualitative methods is to describe the result of this research. This study aims to determine the process and kind of preparation the teacher has in utilizing instructional media and how does the teacher utilize the instructional media in the classroom.

In this research, the teacher was observed and interviewed by the researcher. That the results of this research are in the form of descriptions which are more focused on the process rather than the product of the research because the purpose of this research is to determine the preparation and use of the media used to teach English to the young learner at one of the elementary schools in Cimahi.

The researcher used grade VI for the population and VIB for the sample of the research. This research uses an English teacher in one of the elementary schools in Cimahi as a data source. The school was chosen as the location of the study because of the location of the school and the level of school accreditation. The school has a good level of accreditation is A and the location of the school is near the researcher's house.

\section{RESULTS AND DISCUSSION}

\section{Results}

The data in this study were obtained through two instruments. There are observations in the classroom and interviews with the teacher. Observations were made once. The function of observation is to provide more supportive information for data obtained from respondents in the interview. The researcher observes class 6B taught by an English teacher and consists of 33 students. Data from interviews with teachers is used to confirm and support information about the application of instructional media to young learners at one school in Cimahi.

The first result of observations made began at 08.30 - 09.40 for $2 \times 35$ minutes with the teaching material "Go Green Save the Earth". The activities carried out during the learning process are divided into 3 activities namely preliminary activities, core activities, and closing activities.

In the preliminary activities, the teacher greets the students and asks what kind of breakfast with the English menu to use for the students in the class. After that the teacher absent students and continued with answering guesses related to "job", "place", "country", "person", "animal", "shape". The teacher repeats the material about "Go Green Save the Earth" and then gives a class scenario that there will be a division of groups according to the line that will play about the material using the "Ranking 1" method.

The teacher gives some pictures of "Go Green Save the Earth" in the PowerPoint that is displayed with the projector. Students are then asked to discuss with the group to answer the exact expression following the material that has been taught. After finishing playing Rank 1, the teacher gives the learning objectives learned that day and provides information about the next meeting material which is about "money". Last is the closing activity with a little game of black and green pat.

The second result comes from the interview that the media used during the learning process are projectors and PowerPoint. The reason why the teacher chose the media was that it was easy and could attract the attention of students and save energy in learning. The difficulties encountered when using these media are unstable electricity voltage and projector availability. Preparations for using the media are material for teaching in class, making PowerPoints with laptops, and projectors.

\section{Discussion}

\section{A. The Teacher's Preparation in Utilizing the Visual Media}


The researcher took data to determine teacher preparation in using visual media from the lesson plan, observation directly in the classroom and direct interviews conducted with the teacher. The teacher prepares the projector and understands the material to be delivered to students and prepares instructional media in the form slide of PowerPoint made by the teacher. According to Akmal (2019), the teacher used media electronics for media in the classroom.

The preparations made by the teacher in preparing the material do not experience difficulties. The material that will be given to students is material that comes from the syllabus that is applicable by the government. In instructional media especially visual media, the preparation only has constraints such as limited school facilities and financial support for the procurement of learning media which is a factor in the way teachers choose the right learning media, teachers only utilize the learning media available in schools. However, to use other learning media, teachers must pay to make learning media. Unstable school electricity that makes teachers unable to apply instructional media in the classroom. And other obstacles such as English is a content subject that has one meeting in one week which requires the teacher to be more selective in choosing instructional media that is suitable for the material and characteristics of students.

\section{B. The Ways the Teacher Utilizes the Visual Media in the Classroom}

The researcher observes to find out how to teach by utilizing the classroom learning media once. In this study, the researcher found that teachers use PowerPoint, projectors, laptops, whiteboards, and textbooks that have been provided by the government.

The first is a PowerPoint. It used by the teacher as a medium to deliver material taught to students. Powerpoint is one of the media that is easily made by teachers and more energy efficient to explain the material to students. The slide of PowerPoint used by the teacher contains pictures related to the material so that it is easily understood by students and attracts more attention so that the focus is still paying attention to the teacher. Heinich, et al (2002) as cited in Senjaya, Batan, and Myartawan (2018) one type of media is a slide and it is visual media.

The second is a projector. Harmer (2007) as cited in Muslaini, Kristina, and Ngadiso (2018) that this instructional media has two vital components. They are hardware and software. The hardware needed for this instructional media is computer and LCD projector. It used by the teacher to support learning on PowerPoint to display PowerPoint so that it can be seen by all students in the class. The third is a laptop. It is an electronic device that has many uses, one of which is to make PowerPoint. The teacher uses a laptop to make an interesting PowerPoint so that students can pay more attention to the material and focus while learning takes place.

The fourth is the whiteboard. The purpose of the blackboard used by the teacher in observation is to use the blackboard as a photo frame to display slides on a PowerPoint so that it can be seen by students. The fifth is the textbook provided by the government. In this observation, the book is a reference used by the teacher to explain what material will be delivered to students and only the teacher has the book.

When delivering the material, the teacher does not feel difficulties except that the external is less supportive of the teacher using these media such as the instability of the school's electricity voltage which results in the inconvenience of all electricity running 
simultaneously and the projector cannot be used as well as the availability of inadequate projectors which only have a few projectors and must take turns with other teachers.

\section{CONCLUSION}

The researcher found data about how teachers prepare for preparing instructional media for classroom learning and how teachers utilize instructional media in the learning process in class in the results of observations and interviews. First, in this case, the teacher chooses instructional media following the material being taught and studies the material that will be delivered to students. the teacher tried to achieve the goal in teaching which was encouraging the students to communicate in English simply used in the classroom. The second, the use of visual media, teachers helped by the media they use for teaching English.

\section{ACKNOWLEDGMENTS}

Alhamdulillahirabbil'alamin, praise and thank you to Allah SWT. I would like to express my gratefulness who helped, guided, and supported in writing and finishing this article and praise God for the blessings given to authors so that I complete this article.

\section{REFERENCES}

Akmal. (2019). The Use of Audio-Visual Media in Speaking Ability of English Speaking Club Students at STMIK Royal Kisaran. Journal Of Science And Social Research, 4307(February), 1-6.

Aziz, A., \& Rif'ah, D. (2018). The Effectiveness of Using Audio-Visual Media to Develop Students' pronunciation in Speaking Skill (An Experimental Research the Second Grade of SMP Negeri 2 Bajeng). Brilliance Journal, 3(02).

Aziza, W., \& Syafei, A. F. R. (2018). Using Cartoon Film Series "Shawn The Train" As Media in Teaching Vocabulary to Young Learners. Journal of English Language Teaching, 7(1), 112-122.

Cahyati, S. S., Parmawati, A., \& Atmawidjaja, N. S. (2019). Optimizing English Teaching and Learning Process to Young Learners ( A Case Study In Cimahi ). Journal of Educational Experts, 2(2), 107-114.

Harisma, I., Ilmiah, G., \& Yana, Y. (2019). Improving Students'Writing Ability Through Project Based-Learning using Visual Media. PROJECT (Professional Journal of English Education), 2(3), 364-370.

Isnaini, Y., \& Lisani, F. (2019). The Effect of Line Drawing in Teaching English Vocabulary at the Seventh Grade Students of SMPN 19 Mataram in Academic Year 2016/2017. Linguistics and ELT Journal, 5(1), 12-22.

Lelawati, S., Dhiya, S., \& Mailani, P. N. (2018). The Teaching Of English Vocabulary to Young Learners. PROJECT (Professional Journal of English Education), 1(2), 95-100.

Mohajan, H. K. (2018). Qualitative Research Methodology in Social Sciences and Related Subjects. Journal of Economic Development, Environment, and People, 7(01), 22-48. https://doi.org/10.1007/BF01591250

Muslaini, F., Kristina, D., \& Ngadiso, N. (2018). A Call for Barriers in Implementation of Education Regulation: the Latest English Textbook as Main Instructional Media in Schools in Indonesia. International Journal of Multicultural and Multireligious Understanding, 5(2011), 38-44.

Mustafa, M. N., Hermandra, \& Zulhafizh. (2019). Teachers' Strategies to Design Media to Implement Communicative Leaning in Public Schools. Journal of Educational Sciences, 
$3(1), 13-24$.

Nurnaningsih, Arianti, A. (2019). The Usage of Youtube Video in Teaching English for Young Learner (TEYL) for Sixth Semester Students of English Department. Cordova Jurnal, 9(1), 1-16.

Rachmijati, C., \& Anggraeni, A. (2019). The Study of the Use Of Popular Novels to Improve Reading Interest and English Proficiency. JOALL (Journal of Applied Linguistics and Literature), 4(1), 54-59. https://doi.org/10.33369/joall.v4i1.6880

Rahmadani, S. (2019). Investigating the Implementation of TPR Approach in English Language Teaching for Children (Doctoral dissertation, UIN Ar-Raniry Banda Aceh).

Senjaya, I. B. M. A. D., Batan, G., \& Myartawan, I. P. N. W. (2018). An Analysis of Instructional Media used by the English Teacher in Relation to Students'learning Interest and Motivation in SMP Laboratorium Undiksha. Jurnal Pendidikan Bahasa Inggris undiksha, 5(2). 